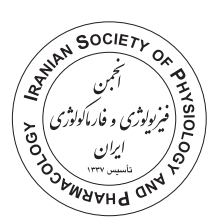

\title{
The effect of vitamin D therapy on glycemic control and biochemical indices in type 2 diabetic patients: a randomized, clinical trial study
}

\author{
Majid Mozaffari ${ }^{1 *}$ (DD, Hamed Hajmoradi ${ }^{1}$, Alireza Moravveji ${ }^{2}$, Fatemeh Sadat Asgarian² ${ }^{2}$ Parastoo Noory ${ }^{3}$
}

1. Department of Internal Medicine, School of Medicine, Kashan University of Medical Sciences, Kashan, Iran

2. Social Determinants of Health Research Center, Kashan University of Medical Sciences, Kashan, Iran

3. Department of Tissue Engineering and Applied Cell Sciences, School of Advanced Technologies in Medicine, Tehran University of Medical Sciences, Tehran, Iran

\section{ABSTRACT}

Introduction: The aim of the present study was to evaluate the effect of vitamin D on glycemic control and biochemical indices in type 2 diabetes.

Methods: This randomized double blind placebo-controlled clinical trial was conducted on 80 patients with type 2 diabetes mellitus (T2DM) referred to Shahid Beheshti hospital. These patients were randomly classified into case and control groups. Case group consumed $50,000 \mathrm{IU}$ of vitamin D once a week for 12 weeks and control group placebo. Biochemical and lipid parameters and vitamin D3 were measured in two groups. Glycosylated hemoglobin (HbAlc) was assessed by latex enhance immunoturbidimetric assay.

Results: There was no significant difference between case and control groups in terms of age, sex, body mass index and used medications. The mean vitamin $\mathrm{D}$ level in case and control groups before intervention was $15.06 \pm 3.307$ and $15.83 \pm 2.509 \mathrm{ng} / \mathrm{ml}$ and after intervention was $49.77 \pm 15.73$ and $14.91 \pm 3.13 \mathrm{ng} / \mathrm{ml}$ respectively. The mean fast blood sugar in case and control groups after intervention was $156.565 \pm 32.23$ and $147.75 \pm 35.06$ $\mathrm{mg} / \mathrm{dl}$, respectively. The mean $\mathrm{HbA} 1 \mathrm{c}$ in case and control groups before intervention was $7.59 \pm 0.39 \%$ and $7.66 \pm 0.38 \%$ and after intervention was $7.26 \pm 0.60$ and $7.60 \pm 0.38$, respectively. Moreover, significant difference was seen between case (20.2 $\pm 5.74 \mathrm{IU} / \mathrm{L})$ and control groups $(23.35 \pm 7.80 \mathrm{IU} / \mathrm{L})$ in terms of alanine aminotransferase, after intervention. Conclusion: According to these findings, vitamin D supplementation possibly through decreasing $\mathrm{HbA1C}$ and hepatic alanine aminotransferase could improve diabetes complications.

\section{Keywords:}

Glycemic control

Type 2 diabetes

Vitamin D

\footnotetext{
* Corresponding author: Majid Mozaffari, Mozaffari-m@kaums.ac.ir

Received 23 October 2019; Revised from 6 December 2020; Accepted 13 December 2020
}

Citation: Mozaffari M, Hajmoradi H, Moravveji A, Asgarian FS, Noory P. The effect of vitamin D therapy on glycemic control and biochemical indices in type 2 diabetic patients: a randomized, clinical trial study. Physiology and Pharmacology 2021; 25: 125-133. http://dx.doi.org/10.32598/ppj.25.2.100 


\section{Introduction}

Diabetes mellitus is caused by a combination of insulin resistance and impaired insulin secretion by pancreatic B cells (Sheikhpour, 2012; Sheikhpour et al., 2010). The World Health Organization predicted that the prevalence of type 2 diabetes (T2DM) will reach from 171 million in 2000 to 366 million in 2030 (Sheikhpour et al., 2010). This prevalence varies in different countries. Moreover, the prevalence of diabetes in Iran was reported 8.7\% (Esteghamati et al., 2010; Zaroudi et al., 2016). Approximately, 4.4 million of adults in Iran have impaired fasting glucose and $70 \%$ of them will develop diabetes (Esteghamati et al., 2008; Nathan et al., 2007). Genetic predisposition, unhealthy diet, modification of lifestyle, reduced physical activity and obesity (fond) are influential factors that affect T2DM (Zaroudi et al., 2016).

Recently, studies have shown the presence of vitamin D receptor and 1- $\alpha$-hydroxylase in the pancreatic $\beta$ cells of humans and animals (Infante et al., 2019). The active metabolite 1 $\alpha, 25$-dihydroxyvitamin D3 (1, $\left.25(\mathrm{OH}){ }_{2} \mathrm{D} 3\right)$ affects pancreatic $\beta$-cells (Infante et al., 2019), insulin secretion and insulin sensitivity (Infante et al., 2019; Ostoglou-Athanassiou et al., 2013). In this regard, the use of vitamin D3 supplementation can lead to normalization of carbohydrate, mineral and lipid metabolism and reduction of pro-inflammatory cytokines, contributing treatment of endocrine diseases in T2DM (Komisarenko and Bobryk, 2018).

Vitamin D deficiency appears to be associated with reduced insulin release, enhanced insulin resistance (Lips et al., 2017, Sheikhpour et al., 2018) and increased risk for development of diabetes mellitus and metabolic syndrome (Pittas et al., 2012; Pittas et al., 2017; Mitri et al., 2011; Chagas et al., 2012; Lim et al., 2013); while the effect of vitamin D supplementation on insulin sensitivity or secretion of insulin was not observed in vitamin D-deficient status (Mousa et al., 2015). In addition, vitamin D enhances expression of lipoprotein lipase gene in adipose tissue and muscles. Activation of lipoprotein lipase affects lipoprotein particles and lipid profiles, contributing reduction of atherosclerosis (Jafari, 2016). Vitamin D supplementation may improve serum biomarkers of liver function (tavakoli et al., 2019). Furthermore, safety and tolerability of vitamin D3 even high-doses oral vitamin D3 (5000 IU/day) was reported in some studies (DeGiorgio et al., 2019; Sheikhpour el.,
2018).

Given that high prevalence of vitamin D insufficiency or deficiency in patients with T2DM (Mariam et al., 2019), high incidence of hyperlipidemia in these patients (Jafari, 2016; Sheikhpour, 2012) and few clinical trial studies regarding the effect of vitamin D supplementation on glycemic status and biochemical parameters in diabetic patients in our region, the aim of current study was to evaluate the effect of vitamin D therapy on glycemic control and biochemical indices in type 2 diabetic patients.

\section{Materials and methods}

\section{Sample selection}

This randomized double-blind placebo-controlled clinical trial study was conducted on 80 diabetic patients at the age range of 30-60 years referred to Shahid Beheshti hospital, Kashan, Iran, during 2019. Informed consent was obtained from all of the participants. Moreover, current study was approved by Kashan University of Medical Sciences with number IR.KAUMS.MEDNT.REC.1398.019. In addition, current study was registered in Iranian Registry of Clinical Trial with number IRCT 20190505043480N1:

Moreover, inclusion criteria were: diagnosis of diabetes over 2 years, definitive diagnosis of type 2 diabetes according to standard criteria, $7<$ glycosylated hemoglobin $(\mathrm{HbA} 1 \mathrm{c})<8$, fast blood sugar $(\mathrm{FBS})<200 \mathrm{mg}$ $\mathrm{dl}$, use of oral hypoglycemic drugs, not taking vitamin D supplements or calcium or medications affecting vitamin D metabolism over the past 3 months, absence of chronic, renal and liver disease and other chronic illness, the level of vitamin D between 10 to $19.9 \mathrm{ng} / \mathrm{ml}$ and willingness to participate in the study.

The exclusion criteria were: FBS $>200 \mathrm{mg} / \mathrm{dl}, \mathrm{HbAlC}>$ 8 , pregnancy, lactation and Malignancy. The number of patients according to power $85 \%, 95 \%$ confidence interval and minimum acceptable difference of $0.5 \%$ for HbAlc was assumed 40 in each group.

$$
N=\frac{2\left(Z_{1}-\frac{\alpha}{2}+Z_{1}-\beta\right)^{2} \times S^{2}}{D^{2}}
$$

\section{Selecting of exclusion criteria}

Then, patients with T2DM were randomly classified into two groups (case and placebo groups) by block randomization method. The patients were randomized 1:1 


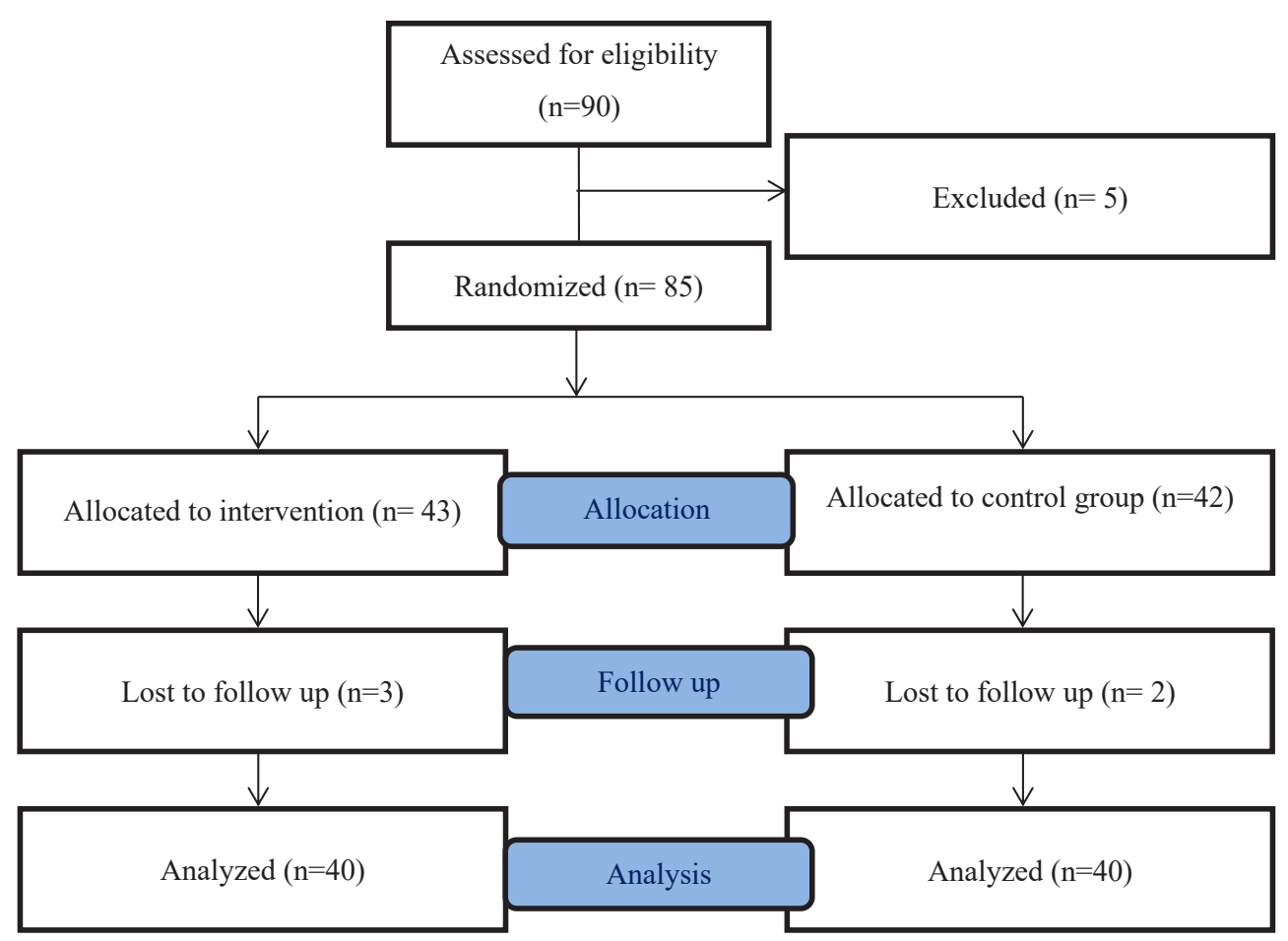

FIGURE 1. Consort flowchart of patients in Shahid Beheshti hospital, Kashan.

according to the method of block randomization with a block size of 10 . No stratification was used. The randomization procedure was performed by the researcher. The researcher team and participants remained blinded until the end of the study. Case group (intervention group) consumed 50,000 IU of vitamin D once a week for 12 weeks and other group placebo. Before and after taking vitamin $\mathrm{D}$, blood samples were taken 8 hours after fasting.

Moreover, demographic and anthropometric characteristics of patients including age, gender, height, weight and duration of diabetes were extracted from medical record and entered to questionnaire.

\section{Evaluation of biochemical and lipid profiles}

After separating serum from blood, biochemical and lipid profiles including triglyceride (TG), low density lipoprotein (LDL), high density lipoprotein (HDL), cholesterol, creatinine, alkaline phosphatase (ALP), alanine aminotransferase (ALT), aspartate aminotransferase, FBS and blood urea nitrogen (BUN) were measured by Greiner Kit (Germany) according to Kit's instructions (based on enzymatic method).

\section{Evaluation of serum vitamin $D$}

The 25(OH)vitamin D3 level were measured before and after taking vitamin D by ELISA method (Greiner kit, Germany) with sensitivity $5 \mathrm{nmol} / 1$ and specificity $100 \%$. Vitamin D level was classified according to the following categories: $<10 \mathrm{ng} / \mathrm{ml}$, deficient; between 10-30 ng/ml, insufficient; between 30-100 ng/ml, sufficient; $>100 \mathrm{ng} / \mathrm{ml}$, potential intoxication.

\section{Evaluation of HbAlc}

For estimation of $\mathrm{HbAlc}$, samples were collected in EDTA anti- coagulant and then assessed by latex enhance immunoturbidimetric assay (Greiner Kit, German ny).

\section{Statistical analysis}

All data were analyzed using the SPSS software (version 20.0, SPSS Inc., Chicago, IL). Baseline characteristics were presented as mean $\pm \mathrm{SD}$ and frequency (\%), The Kolmogorov test was used for determining normality of the parameters and Wilcoxon test and Mann-Whitney test were used for analysis of non-normal distribution variables within and between groups. Independent sample t-test and paired t-test were used for comparison between groups before and after supplementation and within groups for analysis of normal distribution variables. The efficacy analyses to explore the intervention 
TABLE 1: The mean biochemical parameters in two groups before intervention.

\begin{tabular}{|cccc|}
$\begin{array}{c}\text { Biochemical parameters } \\
\text { (Before intervention) }\end{array}$ & $\begin{array}{c}\text { Placebo } \\
\text { (control=40) } \\
\text { Mean } \pm \text { SD }\end{array}$ & $\begin{array}{c}\text { Vitamin D } \\
\text { (case=40) } \\
\text { Mean } \pm \text { SD }\end{array}$ & P-value \\
\hline HbA1C (\%) & $7.59 \pm 0.39$ & $7.66 \pm 0.38$ & 0.460 \\
\hline FBS (mg/dl) & $140.27 \pm 32.69$ & $150.55 \pm 32.23$ & 0.161 \\
\hline LDL (mg/dl) & $99.3 \pm 46.3$ & $102.76 \pm 48.8$ & 0.740 \\
\hline HDL(mg/dl) & $41.3 \pm 13.17$ & $41.9 \pm 11.2$ & 0.801 \\
\hline TG (mg/dl) & $150.67 \pm 53.92$ & $193.15 \pm 82.70$ & 0.008 \\
\hline ALT (IU/L) & $24.1 \pm 8.42$ & $21.3 \pm 6.6$ & 0.101 \\
\hline AST (IU/L) & $24.9 \pm 8.43$ & $22.0 \pm 8.32$ & 0.120 \\
\hline ALP (U/L) & $163.2 \pm 63.3$ & $195.7 \pm 63.8$ & 0.025 \\
\hline BUN(mg/dl) & $19.7 \pm 6.7$ & $17.5 \pm 5.90$ & 0.126 \\
\hline Cr(mg/dl) & $1.03 \pm 0.21$ & $0.92 \pm 0.116$ & 0.011 \\
\hline
\end{tabular}

FBS: fast blood sugar; LDL: low density lipoprotein; HDL: high density lipoprotein; TG: triglyceride; ALT: alanine aminotransferase; AST: aspartate aminotransferase; ALP: alkaline phosphatase; BUN: blood urea nitrogen; Cr: creatinine

TABLE 2: The mean biochemical parameters in two groups after intervention.

\begin{tabular}{cccc}
$\begin{array}{c}\text { Biochemical parameters } \\
\text { (after intervention) }\end{array}$ & $\begin{array}{c}\text { Placebo (control=40) } \\
\text { Mean } \pm \text { SD }\end{array}$ & $\begin{array}{c}\text { Vitamin D } \\
\text { (case=40) } \\
\text { Mean } \pm \text { SD }\end{array}$ & P-value \\
\hline HbA1C (\%) & $7.60 \pm 0.38$ & $7.26 \pm 0.60$ & 0.002 \\
\hline FBS (md/dl) & $147.75 \pm 35.06$ & $156.565 \pm 32.23$ & 0.245 \\
\hline LDL (md/dl) & $92.77 \pm 29.66$ & $87.77 \pm 39.63$ & 0.525 \\
\hline HDL (md/dl) & $41.6 \pm 9.83$ & $42.9 \pm 10.89$ & 0.590 \\
\hline TG(md/dl) & $142.17 \pm 46.95$ & $152.27 \pm 55.78$ & 0.380 \\
\hline ALT (IU/L) & $23.35 \pm 7.80$ & $20.2 \pm 5.74$ & 0.033 \\
\hline AST (IU/L) & $23.50 \pm 8.04$ & $21.77 \pm 8.21$ & 0.340 \\
\hline ALP (U/L) & $165.17 \pm 59.56$ & $170 \pm 64.3$ & 0.720 \\
\hline BUN (md/d) & $17.67 \pm 5.11$ & $16.95 \pm 5.28$ & 0.540 \\
\hline Cr (md/dl) & $1.05 \pm 0.25$ & $0.96 \pm 0.20$ & 0.084 \\
\hline
\end{tabular}

FBS: fast blood sugar; LDL: low density lipoprotein; HDL: high density lipoprotein; TG: triglyceride; ALT: alanine aminotransferase; AST: aspartate aminotransferase; ALP: alkaline phosphatase; BUN: blood urea nitrogen; Cr: creatinine

effect were based on intent-to-treat protocol, A two-sided $\mathrm{P}$ value, 0.05 was considered as statistically significant.

\section{Results}

This study was conducted to evaluate the effect of vitamin D therapy on glycemic control and biochemical parameters on 80 patients with T2DM. Among these patients, 31 patients $(38.8 \%)$ were male and $49(61.2 \%)$ were female. No significant difference was seen between two groups, in terms of sex $(P=0.323)$. The mean age of patients in case and control groups was $55.1 \pm$
9.4 and $55.8 \pm 12.28$ years, respectively $(P=0.72)$. Body mass index (BMI) in two groups was $29.66 \pm 4.580$ and $29.39 \pm 4.58$, respectively $(P=0.8)$. It indicates that both groups were matched, regarding age and BMI.

The mean vitamin $\mathrm{D}$ level before intervention in placebo and case groups was $15.83 \pm 2.509$ and 15.06 $\pm 3.307 \mathrm{ng} / \mathrm{ml}$, respectively $(P=0.24)$. The mean vitamin $D$ level after intervention in placebo and case groups was $14.91 \pm 3.13$ and $49.77 \pm 15.73 \mathrm{ng} / \mathrm{ml}$, respectively $(P<0.001)$. As demonstrated in Table 1, significant difference was seen between two groups, regarding TG, ALP and creatinine, before intervention $(P<0.05)$. In 
TABLE 3: Drug used between case and control groups.

\begin{tabular}{|c|c|c|c|}
\hline & $\begin{array}{c}\text { Placebo } \\
\mathbf{N}=\mathbf{4 0}\end{array}$ & $\begin{array}{c}\text { Case } \\
\mathrm{N}=40\end{array}$ & $P$-value \\
\hline $\begin{array}{c}\text { Metform } \\
\text { No } \\
\text { Yes }\end{array}$ & $\begin{array}{c}1(2.5) \\
39(97.5)\end{array}$ & $\begin{array}{c}0(0) \\
40(100)\end{array}$ & 1 \\
\hline $\begin{array}{c}\text { Gliclazi } \\
\text { No } \\
\text { Yes }\end{array}$ & $\begin{array}{l}14(35) \\
26(65)\end{array}$ & $\begin{array}{l}19(47.5) \\
21(52.5)\end{array}$ & 0.364 \\
\hline $\begin{array}{c}\text { Sitaglipt } \\
\text { No } \\
\text { Yes }\end{array}$ & $\begin{array}{c}39(97.5) \\
1(2.5)\end{array}$ & $\begin{array}{c}36(90) \\
4(10)\end{array}$ & 0.359 \\
\hline $\begin{array}{c}\text { Acarbo } \\
\text { No } \\
\text { Yes }\end{array}$ & $\begin{array}{c}36(90) \\
4(10)\end{array}$ & $\begin{array}{c}36(90) \\
4(10)\end{array}$ & 1 \\
\hline $\begin{array}{c}\text { Pioglitaz } \\
\text { No } \\
\text { Yes }\end{array}$ & $\begin{array}{c}39(97.5) \\
1(2.5)\end{array}$ & $\begin{array}{c}40(100) \\
0(0)\end{array}$ & 1. \\
\hline $\begin{array}{c}\text { Repaglin } \\
\text { No } \\
\text { yes }\end{array}$ & $\begin{array}{c}40(100) \\
0(0)\end{array}$ & $\begin{array}{c}39(97.5) \\
1(2.5)\end{array}$ & 1 \\
\hline
\end{tabular}

this regard, the mean TG and ALP in control group was significantly less than case group. However, the mean creatinine in control group was significantly higher than case group.

As shown in Table 2, significant difference was seen between two groups in terms of HbAlc and ALT after intervention $(P<0.01)$. In this regard, the mean ALT and $\mathrm{HbAlc}$ in case group was significantly less than control group.

As shown in Table 3, there was no significant difference between two groups, regarding used medication including metformin $(P=1)$, gliclazide $(P=0.364)$, sitagliptine $(P=0.359)$, acarbose $(P=1)$, pioglitazone $(P=1)$ and repaglinide $(P=1)$.

\section{Discussion}

In current study the status of vitamin $\mathrm{D}$ in patients with diabetes was evaluated and mean level of vitamin $\mathrm{D}$ in case and control groups before intervention was reported as $15.06 \pm 3.307$ and $15.83 \pm 2.509 \mathrm{ng} / \mathrm{ml}$. It indicates that the mean level of vitamin $\mathrm{D}$ in type 2 diabetic patients was insufficient. Thnc et al. (2011) evaluated the status of vitamin $\mathrm{D}$ in children and adolescent with diabetes and reported that $43 \%$ of diabetic patients have vitamin D insufficiency. it has been reported that the incidence of vitamin D deficiency or insufficiency varies from 70 to $90 \%$ (Laway et al., 2014; Hidayat et al., 2010; Athanassiou et al., 2013; Mezza et al., 2012; Brijesh and Saurav, 2014). The prevalence of vitamin D deficiency in diabetic patients in South India was $84 \%$ (Modi et al., 2015). Saedisomeolia et al. (2014) reported that prevalence of vitamin D deficiency in diabetic patients was $58.34 \%$. It seems that vitamin D deficiency and insufficiency was common in patients with T2DM.

The level of ALT in current study was significantly decreased after treatment with vitamin D. In addition, the mean ALP before and after intervention with vitamin D was $195.7 \pm 63.8$ and $170 \pm 64.3 \mathrm{U} / 1$, respectively. This seems that vitamin D reduced ALP level. Hariri and zohdi (2019) in a randomized double blind clinical trial study observed that vitamin D therapy decreases the level of liver enzymes including ALT and aspartate aminotransferase. Tavakoli et al. (2019) observed the useful effect of vitamin D on ALT level. It is believed that vitamin D supplementation may improve biomarkers of liver function in adolescents. Given that liver is a main organ in metabolism of vitamin $\mathrm{D}$, the inverse relation between liver enzymes and vitamin D may be due to decreased 25-a hydroxylation of vitamin D in the liver (Shehata and Qayyum, 2016). Vitamin D may indirectly influence hepatocytes via activating or inhibiting nonparenchymal liver cells such as sinusoidal endothelial cells, Kupffer cells and stellate cells which may change hepatocyte milieu (Shehata and Qayyum, 2016). 
Foroughi et al. (2014) evaluated the effect of vitamin D (50000 IU/week) on liver enzymes and observed no changing in liver enzyme levels.

In present study, vitamin D supplementation did not affect FBS, but decreased $\mathrm{HbA} 1 \mathrm{c}$ in these patients. Lips et al. (2017) did not observe significant effects of vitamin D supplementation on glycemic control. Mariam et al. (2019) found no relation between vitamin D level and glycemic status. The finding of this study was consistent with our study (Akha et al, 2015). assessed the effect of vitamin D on glycemic control in diabetic patients with moderate and severe vitamin D deficiency. They observed that vitamin D therapy did not affect serum glucose level, which was consistent with our study. It seems that fasting blood glucose in diabetic individuals undergoes significant changes on different days and even different hours in a day and is not a good indicator for assessing the state of diabetes control (Sheikhpour et al., 2011).

Buhary et al. (2017) assessed relation between HbA1c and serum vitamin D level and observed inverse relation between them. The finding of this study was consistent with our study. It seems that vitamin D through increasing activity of pancreatic beta cells may prevent the increases of glycosylated hemoglobin. The effects of vitamin $\mathrm{D}$ on synthesis and secretion of insulin was also seen in some studies (Calle et al., 2008). Fondjo et al. (2017) observed that low level of vitamin D was associated with impaired sensitivity of insulin. It operates as a ligand for vitamin D receptor (Eftekhari et al., 2011). This receptor regulates gene expression as a vitamin D-dependent transcription factor. It exerts this action by binding of promoter regions of target genes (Calle et al., 2008). Saedisomeolia et al. (2014) reported that vitamin $\mathrm{D}$ has direct and indirect effects on insulin secretion, insulin resistance and $\beta$-cell function via both genomic and non-genomic ways. Eftekhari et al. (2011) reported that the direction of changes in serum insulin and $\mathrm{HbA} 1 \mathrm{c}$ was similar. Limitation of our study was that serum insulin level was not measured. Therefore, in our study, insulin secretion may have been affected by vitamin D. But Mousa et al. (2015) reported that the use of highdose vitamin D supplementation did not affect insulin sensitivity or insulin secretion in overweight or obese adults in vitamin D-deficient status. They concluded that vitamin D supplementation could not be considered as an effective strategy for decreasing diabetes risk even in vitamin D-deficient status. It seems that dosage of medication, type of vitamin D (oral or infusion), duration of usage, status of vitamin D and BMI may be influential factors on insulin secretion and diabetes status.

Moreover, we did not observe significant difference between case and control groups, regarding lipid profile after intervention. However, the mean level of LDL before and after intervention was $102.76 \pm 48.8$ and $87.77 \pm 39.63$, respectively. The mean level of TG before and after intervention was $193.15 \pm 82.70$ and $152.27 \pm 55.78$, respectively. It seems vitamin D decreases LDL and TG. Saedisomeolia et al. (2014) assessed the status of lipid profiles in diabetic patients and reported inverse relation between serum level of vitamin D and TG. It is believed that vitamin D increases the activity of lipoprotein lipase in status of adiposity. John et al. (2005) conducted a study on Bangladeshi adults with no history of diabetes and did not observe any relation between 25(OH) D and TG or HDL cholesterol. Duration of diabetes disease may be the reason of difference between studies. (Nouri Saeidlou et al, 2017) reported that the level of serum vitamin $\mathrm{D}$ is different in two seasons. Moreover, there was significant relation between vitamin D and lipid profiles including cholesterol, LDL and HDL in terms of seasons (Saedisomeolia et al., 2014). it has been reported that vitamin D deficiency was associated with increased risk of dyslipidemias, particularly in men. This association may differ by genders. However, mechanism that vitamin D affects lipid profile is not clear. Some studies proposed that increasing intestinal calcium absorption could decrease the synthesis and secretion of hepatic triglyceride (Wang et al., 2016; Cho et al., 2005). Vitamin D can inhibit synthesis and secretion of triglyceride via stimulating of absorption of intestinal calcium. It has been suggested that increased level of intestinal calcium decreases absorption of fatty acid from intestine due to insoluble calcium-fatty complexes formation (Wang et al, 2016; Christensen et al., 2009).

In addition, vitamin $\mathrm{D}$ therapy did not significantly decrease creatinine and BUN level compared to placebo in our study. Bently et al. (2013) assessed relation between vitamin D and serum creatinine level and observed no relation between them, which was consistent with our study. Kim et al. (2018) assessed the mean level of creatinine and BUN in patients with vitamin D insufficiency and vitamin D deficiency and observed significant difference between two groups, considering creatinine 
and BUN. In this regard, they observed relation between vitamin D deficiency and increased urine microalbumin/ creatinine ratio. Therefore, findings in this regard are controversy and further studies should be conducted.

\section{Conclusion}

According to these findings, the use of vitamin D in diabetic patients decreased $\mathrm{HbA1C}$ and hepatic ALT and did not adversely affect the FBS, lipid profile, AST, ALP and renal components. Therefore, it seems that vitamin D supplementation could be helpful in improving diabetes complications.

\section{Conflict of interest}

There is no conflict of interest.

\section{Acknowledgment}

This paper is extracted from MD thesis at Kashan University of Medical Sciences. Authors would like to give their gratitude from Kashan University of Medical Sciences for financial support.

\section{References}

Athanassiou I, Athanassiou P, Gkountouras A, Kaldrymides P. Vitamin D and glycemic control in diabetes mellitus type 2. Ther Adv Endocrinol Metab 2013; 4: 122-8. https://doi. org/10.1177/2042018813501189

Bently R. Significant independent predictors of Vitamin $\mathrm{D}$ deficiency in inpatients and outpatients of a nephrology unit. Int J Endocrinol 2013. https://doi. org/10.1155/2013/237869

Brijesh M, Saurav P. Prevalence of vitamin D deficiency in type 2 diabetes mellitus patients and its correlation with glycemic control. Int J Bioassays 2014; 3: 3313-7.

Buhary BM, Almohareb O, Aljohani N, Alrajhi S, Elkaissi S, Sherbeeni S, et al. Association of glycosylated hemoglobin levels with vitamin D status. J Clin Med Res 2017; 9: 1013. https://doi.org/10.14740/jocmr3227w

Calle C, Maestro B, García-Arencibia M. Genomic actions of 1,25-dihydroxyvitamin D3 on insulin receptor gene expression, insulin receptor number and insulin activity in the kidney, liver and adipose tissue of streptozotocin-induced diabetic rats. BMC Mol Biol 2008; 9: 1-2. https://doi. org/10.1186/1471-2199-9-65

Chagas CE, Borges MC, Martini LA, Rogero MM. Focus on vitamin $\mathrm{D}$, inflammation and type 2 diabetes. Nutrients 2012; 4: 52-67. https://doi.org/10.3390/nu4010052
Christensen R, Lorenzen JK, Svith CR, Bartels EM, Melanson EL, Saris WH, et al. Effect of calcium from dairy and dietary supplements on faecal fat excretion: a meta-analysis of randomized controlled trials. Obes Rev 2009; 10: 475-86. https://doi.org/10.1111/j.1467-789X.2009.00599.x

DeGiorgio CM, Hertling D, Curtis A, Murray D, Markovic D. Safety and tolerability of vitamin D3 $5000 \mathrm{IU} /$ day in epilepsy. Epilepsy Behav 2019; 94: 195-7. https://doi. org/10.1016/j.yebeh.2019.03.001

Eftekhari MH, Akbarzadeh M, Dabbaghmanesh $\mathrm{MH}$, Hasanzadeh J. Effects of treatment with oral calcitriol on plasma glucose and insulin levels in non-insulin dependent diabetes mellitus patients. Iranian J Nutr Sci Food Technol 2011; 6: 1-0.

Esteghamati A, Ashraf H, Khalilzadeh O, Rshidi A, Moham$\operatorname{mad} \mathrm{K}$, Asgari F, et al. Trends of diabetes according to body mass index levels in Iran: results of the national Surveys of Risk Factors of Non-Communicable Diseases (1999-2007). Diabet Med 2010; 27: 1233-40. https://doi.org/10.1111/ j.1464-5491.2010.03103.x

Esteghamati A, Gouya M, Abbasi M, Delavari A, Alikhani S, Alaedini $\mathrm{F}$, et al. prevalence of diabetes and impaired fasting glucose in the adult population of Iran national survey of risk factors for non-communicable diseases of Iran. Diabetes Care 2008; 31: 96-8. https://doi.org/10.2337/dc070959

Fondjo LA, Owiredu WK, Sakyi SA, Laing EF. Vitamin D status and its association with insulin resistance among type 2 diabetics: a case -control study in Ghana. PLoS One 2017; 12. https://doi.org/10.1371/journal.pone.0175388

Foroughi M, Maghsoudi Z, Ghiasvand R, Iraj B, Askari G. Effect of Vitamin D supplementation on C-reactive protein in patients with nonalcoholic fatty liver. Int J Prev Med 2014; 5: 969 .

Hariri M, Zohdi S. Effect of vitamin D on non-alcoholic fatty liver disease: a systematic review of randomized controlled clinical trials. Int J Prev Med. 2019; 10: 14-18. https://doi. org/10.4103/ijpvm.IJPVM_499_17

Hidayat R, Setiati S, Soewondo P. The association between vitamin $\mathrm{D}$ deficiency and type 2 diabetes mellitus in elderly patients. Acta Med Indones 2010; 52: 66-7.

Infante M, Ricordi C, Sanchez J, Clare-Salzler MJ, Padilla N, Fuenmayor V, et al. Influence of vitamin D on islet autoimmunity and beta-cell function in type 1 diabetes. Nutrients 2019; 11: 2185. https://doi.org/10.3390/nu11092185

Jafari T. Effects of vitamin D on serum lipid profile in patients with type 2 diabetes: a metaanalysis of randomized 
controlled trials. Clin Nutr 2016; 35: 1259-68. https://doi. org/10.1016/j.clnu.2016.03.001

John WG, Noonan K, Mannan N, Boucher BJ. Hypovitaminosis $\mathrm{D}$ is associated with reductions in serum apolipoprotein A-I but not with fasting lipids in British Bangladeshis. American J Clin Nutr 2005; 82: 517-22. https://doi. org/10.1093/ajcn/82.3.517

Saeidlou SN, Vahabzadeh D, Babaei F, Vahabzadeh Z. Seasonal variations of vitamin $\mathrm{D}$ and its relation to lipid profile in Iranian children and adults. Journal of Health, Population and Nutrition. 2017 Dec;36(1):1-7.

Kim S, Kim GS, Lee JH, Moon AE, Yoon H. The relationship between vitamin $\mathrm{D}$ and estimated glomerular filtration rate and urine microalbumin/creatinine ratio in Korean adults. $\mathrm{J}$ Clin Biochem Nutr 2018; 62: 94-9. https://doi.org/10.3164/ jcbn.17-69

Komisarenko YI, Bobryk MI. Vitamin D deficiency and immune disorders in combined endocrine pathology. Front. Endocrinol 2018; 9: 600. https://doi.org/10.3389/fendo.2018.00600

Laway BA, Kotwal SK, Shah ZA. Pattern of 25 hydroxy vitamin D status in North Indian people with newly detected type 2 diabetes: a prospective case control study. Int J Endocrinol Metab 2014; 18: 726.

Lim S, Kim MJ, Lim S, Kim MJ, Choi SH, Shin CS et al. Association of vitamin D deficiency with incidence of type 2 diabetes in high-risk Asian subjects. Am J Clin Nutr 2013; 97: 542-30. https://doi.org/10.3945/ajcn.112.048496

Lips P, Eekhoff M, van Schoor N, Oosterwerff M, de Jongh R, Krul-Poel Y, et al. Vitamin D and type 2 diabetes. J Steroid Biochem Mol Biol 2017; 173: 280-5. https://oi. org/10.1016/j.jsbmb.2016.11.021

Mariam W, Garg S, Singh MM, Koner BC, Anuradha S, Basu S. Vitamin D status, determinants and relationship with biochemical profile in women with type 2 diabetes mellitus in Delhi, India. Diabetes Metab Syndr: Clinical Rese Rev 2019; 13: 1517-21. https://doi.org/10.1016/j. dsx.2019.03.005

Akha O, Bahar A, Fooldi B, Kashi Z. Effect of vitamin D deficiency correction on glycemic control in patients with type II diabetes mellitus with moderate and severe vitamin D deficiency. Journal of Mazandaran University of Medical Sciences. 2015 Sep 10;25(128):66-76.

Mezza T, Muscogiuri G, Sorice GP, Prioletta A, Salomone E, Pontecorvi A, et al. Vitamin D deficiency: a new risk factor for type 2 diabetes? Ann Nutr Metab 2012; 61: 337-48. https://doi.org/10.1159/000342771
Mitri J, Dawson-Hughes B, Hu FB, Pittas AG. Effects of vitamin $\mathrm{D}$ and calcium supplementation on pancreatic $\beta$ cell function, insulin sensitivity, and glycemia in adults at high risk of diabetes: the Calcium and Vitamin D for Diabetes Mellitus (CaDDM) randomized controlled trial. Am J Clin Nutr 2011; 94: 486-94. https://doi.org/10.3945/ ajcn.111.011684

Modi KD, Ahmed MI, Chandwani R, Kumar KH. Prevalence of vitamin D deficiency across the spectrum of glucose intolerance. J Diabetes Metab Disord 2015; 14: 1-4. https:// doi.org/10.1186/s40200-015-0179-5

Mousa A, Naderpoor N, Teede HJ, De Courten MP, Scragg R, De Courten B. Vitamin D and cardiometabolic risk factors and diseases. Minerva Endocrinol 2015; 40: 213-30.

Nathan DM, Davidson MB, Defronzo RA, Heine RJ, Henry RR, Pratley R, et al. Impaired fasting glucose and impaired glucose tolerance implications for care. Diabetes Care 2007: 3: 753-9. https://doi.org/10.2337/dc07-9920

Ostoglou-Athanassiou I, Athanassiou P. Vitamin D and glycemic control in diabetes mellitus type 2. Ther Adv Endocrinol Metab 2013; 4: 122-8. https://doi. org/10.1177/2042018813501189

Pittas AG, Lau J, Hu FB. and Dawson-Hughes, B. The role of vitamin $\mathrm{D}$ and calcium in type 2 diabetes. A systematic review and meta-analysis. J Clin Endocrinol Metab 2017; 92: 2017-29. https://doi.org/10.1210/jc.2007-0298

Pittas AG, Nelson J, Mitri J, Hillmann W, Garganta C, Nathan $\mathrm{D}$, et al. Plasma 25-hydroxyvitamin D and progression to diabetes in patients at risk for diabetes: an ancillary analysis in the Diabetes Prevention Program. Diabetes Care 2012; 35: 565-73. https://doi.org/10.2337/dc11-1795

Saedisomeolia A, Taheri E, Djalali M, Moghadam AM, Qorbani M. Association between serum level of vitamin D and lipid profiles in type 2 diabetic patients in Iran. J Diabetes Metab Disord 2014; 13: 1-5. https://doi.org/10.1186/22516581-13-7

Shehata E, Qayyum R. The effect of serum vitamin D on serum ALT levels in healthy individuals. J Clin Gastroenterol 2016; 50: 81-4. https://doi.org/10.1097/ MCG.0000000000000459

Sheikhpour E, Sadri Z, Heydari S, Ghanizadeh F, Zare-Zardini $\mathrm{H}$, Atefi A, et al. Vitamin D deficiency and its relation with cancer in children. Iran J Ped Hematol Oncol 2018; 8: 180-6.

Sheikhpour R. A survey on herbal medicines for hypoglycemia in diabetic patients. Iran J Diabetes Obes 2012.

Sheikhpour R, Jalali BA, Yaghmaei P, Afkhami-Ardekani M, 
Rashidi M. Comparison of two supplementary zinc doses on lipid peroxidation in diabetic patients. Iranian J Diab Obes 2010.

Sheikhpour, Jalali-KhanAbadi B, Yaghmaei P, Salmani M H, Afkhami Ardakani M. The effect of zinc supplemention on glycosylated hemoglobin in type II diabetic patients. J Shahrekord Univ Med Sci 2011; 12: 58-63.

Tavakoli H, Rostami H, Avan A, Bagherniya M, Ferns GA, Khayyatzadeh SS, et al. High dose vitamin D supplementation is associated with an improvement in serum markers of liver function. Biofactors 2019; 45: 335-42. https://doi. org/10.1002/biof.1496
Thnc O, Cetinkaya S, Kizilgün M, Aycan Z. Vitamin D status and insulin requirements in children and adolescent with type 1 diabetes. J Pediatr Endocrinol Metab 2011; 24: $1037-$ 41. https://doi.org/10.1515/JPEM.2011.213

Wang Y, Si S, Liu J, Wang Z, Jia H, Feng K, et al. The associations of serum lipids with vitamin D status. PLoS One 2016; 11. https://doi.org/10.1371/journal.pone.0165157

Zaroudi M, Yazdani CJ, Mehrabi S, Ghorbani E, Norouzkhani J, Shirashiani H, et al. Dietary patterns are associated with risk of diabetes type 2: a population-based case-control study. Arch Iranian Med 2016. 